\title{
PROBLEMATIKA PEMANFAATAN BUKU PENDIDIKAN AGAMA ISLAM DI SD NEGERI 11 MANADO DAN SD NEGERI 1 BUNAKEN KEPULAUAN
}

\author{
THE PROBEMATIC NATURE OF THE BOOKS OF ISLAMIC RELIGIONS \\ EDUCATION USED IN STATE SD 11 MANADO AND STATE SD 1 BUNAKEN \\ ISLANDS
}

\author{
Husnul Fahimah Ilyas \\ Balai Penelitian dan Pengembangan Agama Makassar \\ Jl. A.P.Pettarani No.72 Makassar \\ Email: husnul_natalia@yahoo.com
}

Naskah diterima tanggal 8 Maret 2016 naskah direvisi tanggal 28 Maret 2016 Naskah diterima tanggal 3 Juni 2016.

\begin{abstract}
Abstrak
Artikel ini bergenre kebijakan yang berupaya mengungkapkan problem mengenai pemanfatan buku Pendidikan Agama Islam (PAI) di Sekolah Dasar (SD) Negeri 11 Manado dan SD Negeri 1 Bunaken Kepulauan. Permasalahan difokuskan pada ketersediaan buku PAI, mekanisme pemanfaatan, dan problem yang dihadapi oleh pendidik dan peserta didik dalam memanfaatkan buku PAI. Data-data diperoleh dari hasil wawancara, dokumen, dan observasi dan dianalisis dengan pendekatan kualitatif. Hasil penelitian ini menunjukkan bahwa SD Negeri 11 Manado menggunakan buku PAI K-13 untuk kelas I, II, IV, dan V dalam pembelajaran. Ketersediaan buku khususnya buku Pendidikan Agama Islam K-13 di SD Negeri 11 Manado belum maksimal dan masih jauh dari teori ideal karena belum berbanding satu siswa-satu buku. Sekitar 10\% siswa belum mempunyai buku pegangan. Solusinya memfotokopi buku PAI bagi anak mampu secara materi. Sedangkan untuk kelas III dan VI menggunakan buku PAI KTSP 2006 penerbit Erlangga yang disediakan oleh sekolah (menggunakan dana BOS). Berbeda dengan SD Negeri 1 Bunaken Kepulauan, distribusi buku PAI sangat timpang. Untuk buku K-13 khususnya pelajaran agama tidak terjangkau sampai kepulau-pulau. Solusi yang ditawarkan guru PAI mendikte atau menuliskan di papan tulis (khusus kelas I dan VI). Sedangkan kelas II, III, IV, dan V SD Negeri 1 Bunaken Kepulauan, tidak mempunyai buku wajib baik pegangan guru dan siswa yang sesuai standar kurikulum K-13 ataupun KTSP 2006. Hal ini disebabkan guru bidang studi PAI tidak ada, solusinya guru kelas hanya mengajarkan Iqra dan bacaan shalat pada jam pelajaran PAI.
\end{abstract}

Kata kunci: buku, Pendidikan Agama Islam, SD

\begin{abstract}
This article seeks to reveal the genre of problematic policy concerning the utilization of books on Islamic Education (Islamic Education) in State elementary school (SD) 11 Manado and Bunaken Islands Elementary School 1. To be more spesific, the problems are focused on Islamic Education books availability, utilization mechanisms, and problems faced by educators and learners in using Islamic Education book. The data obtained from interviews, documents, and observation also analyzed by qualitative approach. The results of research indicate that state elementary school 11 Manado using the K-13 Islamic Education books in learning process for class I, II, IV, and V. Availability of books, especially on Islamic Education K-13 in state elementary school 11 Manado does not maximize and this matter is still far from the ideal need, because the ratio of books number and students are not comparable for each, one student-one books. In fact, about 10\% of students do not have a handbook. As a solution the Islamic Education book is simply copied by children who are able to have the materially. Whereas for the class III and VI are using KTSP 2006 Islamic Education book published by Erlangga which is provided by the school. In contrast to the state elementary school 1 Bunaken Islands, the Islamic Education book distribution is very disproportionate. For K-13 book, especially in religious studies it is unreachable until the islands. So as solution offered by Islamic Education teacher is dictating or write down the material on the black board (especially class I and VI). While the class II, III, IV, and V state elementary school 1 Bunaken Islands, did not have a good grip textbook for the teacher and the students that was appropriate to the standard curriculum K-13 or KTSP 2006. This is due to teachers of Islamic Education did not exist, As a solution Iqra classroom teachers only teach reading and praying during Islamic Education learning hours.
\end{abstract}

Keywords: books, islamic education, elementary school, Bunaken Islands 


\section{PENDAHULUAN}

$\mathrm{P}$ endidikan Agama Islam di Indonesia telah dimulai pada zaman penjajahan Belanda (Mansur dan Mahfud, 2005: 54-56) dan Jepang. Letak perbedaan antara keduanya. Ketika pada masa penjajahan Belanda membatasi dan melarang Pendidikan Agama Islam diajarkan di sekolah pemerintah. Agak berbeda pada masa penjajahan Jepang, Pendidikan Agama Islam secara resmi boleh diajarkan di sekolah-sekolah pemerintah. Hal ini dilakukan sebagai konsekwensi penggalangan umat Islam agar menjadi sekutu Jepang. Secara politis ini menjadi kemajuan bagi pendidikan Islam di sekolah umum. Namun demikian pengawasan ketat tetap dilakukan oleh penjajah Jepang, sehingga menghambat PAI untuk berkembang. Sulit berkembang bukan berarti terhenti melainkan tetap eksis dari periode ke periode pemerintahan. Eksistensi PAI pada masa awal kemerdekaan dan masa orde baru mendapat pengakuan untuk diajarkan di sekolah umum, meskipun menghadapi kendala. Kendala pertama secara politis yang berkaitan dengan perundangundangan yang cenderung tidak memberikan peran bagi PAI, bahkan tidak mengakomodir PAI di sekolah umum. Pendidikan Agama dipandang sebagai urusan individu dan bukan menjadi tanggung jawab sekolah. Kendala kedua non-politis yang berkaitan dengan sosial budaya maupun keterbatasan sumber PAI itu sendiri. Baik menyakut kurikulum, guru, dan metode pembelajarannya (Hamami, 2004: 178-179).

Mengacu pada konteks (kendala pertama) Pendidikan Agama Islam dirumuskan untuk dijadikan landasan yuridis yang amat penting untuk mengokohkan kedudukan dan perkembangan PAI. Landasan ini termaktup pada rumusan yang dibuat oleh panitia persiapan kemerdekaan, antara lain bertugas menyusun rencana dalam bidang pendidikan/ pengajaran. Panitia tersebut berhasil menyusun rumusan tentang tujuan pendidikan yang amat penting artinya bagi PAI. Isi rumusannya "Dalam garis-garis adab perikemanusiaan, seperti terkandung dalam segala pengajaran agama, maka pendidikan dan pengajaran nasional bersendi agama dan kebudayaan bangsa serta menuju ke arah keselamatan dan kebahagiaan masyarakat".

Pengakuan akan urgensi pendidikan agama di sekolah dimulai dengan usulan BP-KNIP agar pendidikan agama mendapat tempat yang teratur, seksama, dan perhatian yang semestinya. Usulan tersebut mendapat respon positif dari Menteri PPK. Dalam upaya meningkatkan mutu pendidikan, Pemerintah melalui Menteri PPK membentuk Panitia Penyelidik Pengajaran dengan SK Menteri PPK Nomor 104/Bhg.O tanggal 1 Maret 1946 yang beranggotakan 51 orang dan diketuai oleh KI Hajar Dewantoro. Keputusan penting yang ditetapkan oleh Panitia tersebut adalah bahwa agama menjadi salah satu pelajaran yang diberikan di Sekolah Rakyat (SR), guru agama disediakan oleh Kementerian Pendidikan dan dibayar oleh Pemerintah, guru agama harus mempunyai pengetahuan umum dan untuk maksud itu harus didirikan Pendidikan Guru Agama (PGA), dan Pesantren dan madrasah harus dipertinggi mutunya.

Keputusan tersebut ditindaklanjuti dengan diterbitkannya peraturan bersama Menteri Pendidikan Pengajaran dan Kebudayaan dan Menteri Agama Nomor: 1142/Bhg. A (Pengajaran) tanggal 2 Desember 1946 dan Nomor 1285/K-7 (Agama) tanggal 12 Desember 1946 yang berlaku tanggal 1 Januari 1947. Surat Keputusan bersama itu menetapkan bahwa pendidikan Agama diberikan mulai kelas IV sampai dengan kelas VI Sekolah Rakyat. Sedang untuk kelas I, II, dan III Pendidikan Agama tidak boleh diberikan. Untuk mengatur pelaksanaan dan materi pelajaran agama di sekolah umum, pada tahun 1947 pemerintah membentuk Majelis Pertimbangan Pengajaran Agama Islam yang dipimpin oleh KI Hajar Dewantoro dari Departemen PPK dan Prof. Drs. Abdullah Sigit dari Departemen Agama.

Dalam Undang-Undang Republik

Indonesia Nomor 2 Tahun 1989 Tentang Sistem Pendidikan Nasional Pasal 11 ayat 1 menyatakan jenis pendidikan yang termasuk jalur pendidikan sekolah terdiri atas pendidikan umum, pendidikan kejuruan, pendidikan luar biasa, pendidikan kedinasan, pendidikan keagamaan, pendidikan akademik, dan pendidikan profesional. Dalam Pasal tersebut juga disebutkan pada Ayat 6 bahwa pendidikan keagamaan merupakan pendidikan yang mempersiapkan peserta didik untuk dapat menjalankan peranan yang menuntut penguasaan pengetahuan khusus tentang ajaran agama yang bersangkutan. Undang-Undang tersebut kembali ditegaskan dalam Undang-Undang No.20 Tahun 2003 dijelaskan pada ayat 1 bahwa pendidikan adalah usaha sadar terencana untuk mewujudkan suasana belajar dan proses pembelajaran agar peserta didik secara aktif mengembangkan potensi dirinya untuk memiliki kekuatan spiritual keagamaan, 
pengendalian diri, kepribadian, kecerdasan, akhlak mulia, serta keterampilan yang diperlukan dirinya, masyarakat, bangsa dan negara. Mengacu pada landasan yuridis yang telah dibuat dari priode ke priode mengindikasikan pentingnya pendidikan agama dan keagamaan yang diarahkan di Sekolah.

Setelah landasan yuridis PAI ada bukan berarti persoalan sudah selesai. Sekelumit permasalahan mulai muncul dalam menerapkan pola pembelajaran PAI di sekolah, menyangkut guru PAI, SDM, peserta didik, sarana, dan prasarana, serta sumber belajarnya termasuk buku PAI.

Berdasar pada latar belakang yang menjadi permasalahan dalam penelitian ini adalah: Bagimana ketersediaan buku Pendidikan Agama Islam di SD Negeri 11 Manado dan SD Negeri 1 Bunaken Kepulauan? Bagaimana mekanisme pemanfaatan buku-buku paket PAI di SD Negeri 11 Manado dan SD Negeri 1 Bunaken Kepulauan? Bagaimana problem yang dihadapi oleh pendidik dan peserta didik dalam memanfaatkan buku PAI di SD Negeri 11 Manaddo dan SD Negeri 1 Bunaken Kepulauan?. Penelitian ini bertujuan untuk mengetahui problematika yang dihadapi dalam hal pemanfaatan buku Pendidikan Agama Islam di satuan pendidikan Sekolah Dasar di Sulawesi Utara, mengetahui ketersediaan Buku Pendidikan Agama Islam baik buku wajib maupun buku penunjang di Sekolah Dasar, mengetahui mekanisme pemanfaatan bukubuku paket PAI di Sekolah Dasar baik dan kreatifitas cara pemanfaatannya oleh pendidik, maupun peserta didik, dan untuk mengetahui problem yang dihadapi oleh pendidik dan peserta didik dalam memanfaatkan buku PAI di Sekolah Dasar.

\section{Kajian Pustaka}

Pentingnya keberadaan buku PAI sebagai salah satu persoalan dalam merealisasikan pembelajaran PAI, hal inilah yang mendorong melakukan penelitian ini. Penelitian Mengenai buku PAI ini bukan hal yang pertama dilakukan. Beberapa penelitian yang relevan dengan penelitian ini diantaranya: penelitian Penggunaan Buku Pendidikan Agama Islam dan Budi Pekerti Kelas VII Terbitan Kemendikbud Tahun 2013 Sebagai Bahan Ajar Mata Pelajaran PAI Siswa SMPIT Abu Bakar Yogyakarta oleh Rahmini. Hasil penelitian ini mengungkapkan bahwa SMPIT Abu Bakar Yogya menerima positif keberadaan buku PAI dan Budi Pekerti. Penerimaan ini dilandasi atas dasar bukunya berkualitas kerena sesuai dengan standar BSNP dan sesuai dengan ideologi kurikulumnya, sehingga buku terbitan Kemendikbud dapat dijadikan refrensi utama dalam proses pembelajaran. Dari segi substansi dan komposisi telah memuat empat kompetensi inti (sikap spitual, sosial, pengetahuan, dan keterampilan. Ditinjau dari segi materinya korelatif dengan KI dan KD K-13 serta materinya lengkap. Bahasa sesuai dengan kebutuhan peserta didik dan memuat unsur-unsur motivasi. Kekurangan buku terbitan Kemendikbud tidak terdapat footnote, warna kurang variatif, materi kurang sistematis, dan buku mudah rusak (Rahmini, 2014).

Penelitian Muhammad S.Rahman mengenai Urgensi Penggunaan Sumber-Sumber belajar Terhadap Peningkatan Efektifitas Belajar Siswa dalam Bidang Studi Pendidikan Agama di SMU Negeri 4 Manado (S.Rahman, 2013) hasil penelitian menyatakan sumber-sumber belajar di SMU Negeri 4 Manado sangat minim bahkan buku paket bidang studi Pendidikan Agama Islam (PAI) hanya diadakan sendiri oleh guru PAI sedangkan di perpustakaan hanya tersedia Alquran saja dalam jumlah yang cukup. Dengan sumber-sumber belajar yang tidak memadai maka keefektifan belajar siswa sangat terganggu karena buku paket tersebut hanya dalam bentuk kopian dan tanpa buku atau bahan perbandingan lainnya.

Kedua penelitian yang telah dilakukan tersebut terdapat berbeda dengan penelitian ini. Namun terdapat pula kesamaan dari segi objek penelitian, Rahmini lebih fokus pada satu buku PAI dan melakukan pengkajian teks terhadap isi buku PAI Kelas VII K-13 terbitan Kemendikbud. Sedangkan penelitian Muhammad S.Rahaman lebih banyak mengulas sumber-sumber belajar sebagai objek penelitian di antaranya buku paket yang digunakan dalam proses pembelajaran. Perbedaan dari kedua penelitian tersebut, penelitian ini lebih spesifik pada Buku-Buku Paket PAI yang digunakan sebagai bahan ajar di SD baik yang terkait dengan problematikanya dan pemanfatan buku PAI.

\section{METODE PENELITIAN}

Penelitian ini merupakan penelitian deskriptif kualitatif dengan melakukan penelusuran problematika pemanfaatan buku PAI di SD Negeri 11 Manado dan SD Negeri 1 Bunaken Kepulauan. Pemilihan dua sekolah sasaran yaitu SD Negeri 11 Manado dan SD Negeri 1 Bunaken Kepulan, dengan pertimbangan: SD Negeri 11 Manado, berada di pusat kota Manado sehingga akses informasi 
yang terkait dengan pendidikan mudah diperoleh. Terakreditasi A total penilaian evaluasi diri dari 8 komponen 93,00. Sedangkan hasil visitasi 90,00 (BAP-S/M Provinsi Sulawesi Utara). Dijadikan sebagai SD sasaran K-13 (piloting project); termasuk SD yang berprestasi; sarana dan prasananya memadai.

Berbeda dengan SD Negeri 1 Bunaken Kepulauan, jauh dari pusat kota dan termasuk dalam kategori wilayah terpencil. Jauh dari akses informasi, sehingga rumit memperoleh informasi yang up to date. Tidak terakreditasi serta sarana dan prasarananya belum memadai. Dalam melakukan analisis terhadap hal-hal spesifik dalam penyelenggaraan pendidikan yang menggunakan buku sebagai media belajar.

\section{HASIL DAN PEMBAHASAN \\ Potret Agama dan Guru Pendidikan Agama Islam di Manado}

Jumlah penduduk menurut agama di kota manado yang tersebar disembilan kecematan/kota. Beragama Islam: 130.517 jiwa, Protestan: 184.628 jiwa, Katolik: 33737 jiwa, Hindu: 2592 jiwa, Budha: 2440 jiwa, Kongfuchu: 242 jiwa (BPS Sulawesi Utara 2014). Berdasarkan data jumlah penduduk menunjukkan bahwa kebutuhan pendidikan agama sangatlah dibutuhkan untuk penganut agama masing-masing baik di lingkungan keluarga maupun di sekolah. Dalam penyelenggaraan pendidikan agama di sekolah formal, khususnya di Pendidikan Agama Islam di SD hanya terdapat 79 guru PAI. Guru-guru PAI tersebut tersebar di sekolah SD negeri dan swasta. Guru PAI khusus di SD Negeri sebanyak 71 orang. Sedangkan 8 orang di tempatkan di sekolah swasta/yayasan. Jumlah SD Negeri di kota Manado sebanyak 121, sedangkan jumlah guru PAI yang tersedia hanya 71 orang. Data ini menggambarkan tidak berbanding rasio guru PAI dengan jumlah sekolah yang membutuhkan guru PAI.

Klaster tingkat pendidikan guru PAI di Kota Manado. Guru PAI tingkat pendidikan Magister (S2) sebanyak 3 (tiga) orang, sarjana (S1) sebanyak 45 orang, diploma sebanyak 31 Orang. Jika merujuk pada UU Nomor 14 tentang Dosen dan Guru telah mensyaratkan berijazah sarjana (S1). Keadaan ini menunjukkan dengan berlakunya UU tersebut guru PAI telah memiliki kesadaran untuk meningkatkan kompetensi dirinya. Terdapat 3,8\% telah berijazah S2 yang menunjukkan kualifikasi kademiknya melampaui standar minimal. Sedangkan S1 57\% dan diploma 39,2\%. Pentingnya kualifikasi akademik GPAI, maka pemerintah berupaya meningkatkan kualifikasi akademik para GPAI misalnya program Pendidikan Islam Kemenag yang bekerja sama dengan STAIN Manado. untuk program S1 bagi para GPAI.

Status kepegawaian PNS Daerah sebanyak 44 orang, PNS Kementerian Agama sebanyak 16 orang, honorarium sebanyak 19 orang. Tingkatan usia guru PAI yaitu usia 27 tahun 1 orang, usia 30-35 tahun 1 orang, usia 36-40 tahun 5 orang, usia 41-45 tahun 8 orang, usia $46-50$ tahun 15 orang, usia 5155 tahun 13 orang, usia 56-60 tahun 15 orang, dan usia 61 tahun 3 orang, selebihnya 18 orang (yang tidak teridentifikasi). Data ini menunjukkan bahwa usia GPAI yang berusia 27 tahun $1,3 \%$, usia $30-35$ tahun $1,3 \%$, usia $36-40$ tahun $6,3 \%$, usia $41-45$ tahun $10 \%$, usia $46-50$ tahun $19 \%$, usia $51-55$ tahun $16,5 \%$, usia 56-60 tahun 19\%, dan usia 61 tahun 3,8\%, selebihnya yang tidak diketahui $22,8 \%$ yang tidak teridentifikasi (Sumber: Seksi Pendidikan Islam Kementerian Agama Manado, 2014).

\section{Potret Sekolah SD Negeri 11 Manado}

SD Negeri 11 Manado didirikan pada tahun 1957 dengan Surat Keputusan Dinas Pendidikan dan Pengajaran No. 545/1956/PDK. Pokok pemisahan Sekolah Rakyat Negeri 04, Sekolah Rakyat Negeri 05, dan Sekolah Dasar Negeri 11 yang terletak di jalan Hatta. Jadi SD Negeri 11 adalah pemekaran dari sekolah Rakyat Negeri 04 dan Sekolah Rakyat Negeri 05. SD Negeri 11 Manado sekarang terletak di jalan Sarapung No.24 Kelurahan Wenang Utara, Kecamatan Wenang Kota Manado. NPSN/NSS: 40102933/101176003010 status kepemilikan sekolah ini adalah milik pemerintah daerah dengan luas tanah milik $1750 \mathrm{~m} 2$. SK izin oprasionalnya 1 Januari 1910. Pada awalnya SD Negeri 11 Manado dipimpin oleh Doodoh, dan berturut-turut dilanjutkan oleh Lopulalang Aipasa, Arina Karuntu, Sondak Manday, Rondonuwu Poluakan, Jeane Walangitan, Berty Bokong, Selvi Senaen, dan sekarang yang menjadi Kepala Sekolah Dasar Negeri 11 adalah Ibu Deitje Karinda, S.Pd. Pada tahun 2010 sekolah ini terakreditasi A berdasarkan pada Surat keputusan 1082/BAP S/M-SULUT/XII/2010 tertanggal 29 Desember 2010. Waktu penyelenggaraan sekolah 12 Jam.

Visi sekolah yaitu berimtaq, berkualitas, berdaya saing tinggi, mencintai seni budaya daerah, peduli terhadap pelestarian lingkungan hidup. 
Sedangkan misinya: menumbuhkan semangat keunggulan secara intensif kepada semua warga sekolah; menerapkan manajemen partisipatif dengan melibatkan seluruh warga sekolah dan stake holder; aktualisasi potensi siswa dari aspek kognitif, afektif, dan psikomotorik untuk meraih potensi terbaik dalam setiap kegiatan; pelaksanaan pembelajaran dan bimbingan secara kreatif, inovatif, dan efektif sehingga setiap siswa dapat berkembang secara optimal sesuai potensi yang dimilikinya; menumbuhkan penghayatan terhadap ajaran agama dan budaya bangsa sehingga menjadi sumber kearifan dalam bertindak; melaksanakan kegiatan olahraga secara optimal untuk meningkatkan kesegaran jasmani dan prestasi siswa; melaksanakan kegiatan kesenian yang berpijak pada budaya bangsa; serta menumbuhkan semangat dan kepedulian terhadap pelestarian lingkungan hidup.

Tujuan sekolah SD Negeri 11 Manado yaitu semua warga sekolah telah melaksanakan program sekolah; meningkatkan semangat belajar mengajar bagi siswa dan guru untuk meraih prestasi yang optimal; melaksanakan tugassesuai dengan tatatertib sekolah; transparan dalam kegiatan manajemen sekolah; melibatkan semua warga sekolah dan stake holder untuk berpartisipasi aktif dalam lomba guru berprestasi tingkat kota, provinsi, dan nasional; setiap hari, sebelum pelajaran dimulai, siswa kelas III-VI membaca diam selama 15 (dalam hati) menit; setiap kelas memiliki sudut baca; rata-rata standar kompetensi lulusan 7,0; meraih prestasi tertinggi dalam pembuatan karya teknologi sederhana; warga sekolah menguasai teknologi dan informasi; melakukan bimbingan secara intensif kepada siswa yang mengalami masalah belajar, pribadi, dan sosial; pemberian reward kepada warga sekolah yang berprestasi; warga sekolah melaksanakan kegiatan keagamaan sesuai dengan kepercayaan yang dianut; menciptakan kerukunan antar warga sekolah dengan cara menghargai perbedaan suku, agama, ras, dan golongan; melaksanakan kegiatan senam bersama di halaman sekolah setiap hari Jumat sebelum kegiatan belajar mengajar dimulai pada hari Minggu pertama dan ketiga; meraih prestasi tertinggi pada kegiatan $\mathrm{O} 2 \mathrm{SN}$ di tingkat kecamatan, kota, provinsi, dan nasional; melaksanakan pagelaran seni pada moment-moment tertentu dengan melibatkan warga sekolah, masyarakat, dan unit dinas; meraih prestasi tertinggi pada kegiatan FL2SN di tingkat kecamatan, kota, provinsi, dan nasional; melaksanaan kegiatan ekstra kurikuler di bidang kesenian untuk mengembangkan budaya khas Sulawesi Utara berkolaborasi dengan budaya daerah lain yang ada di Indonesia; menjadi sekolah adhiwiyata tingkat kota, provinsi, dan nasional; melaksanakan kegiatan kebersihan setiap hari di lingkungan sekolah sebelum kegiatan belajar mengajar dimulai selama 15 menit dan Jumpa Berlian (Jumat Pagi Bersih Lingkungan) setiap hari Jumat selama 30 menit; menjadi sekolah sehat di tingkat kecamatan, kota, provinsi, dan nasional; setiap kelas tersedia alat kebersihan dan memiliki taman hijau serta pajangan yang tertata rapi; serta mengadakan perindangan sekolah tampak hijau dan asri.

Seiring dengan perkembangan pendidikan di SD Negeri 11 Manado, maka arus murid berasal dari semua kecamatan yang ada di kota Manado. Pada tahun 1968 sebagian SD Negeri 11 Manado mengalami kebakaran sehingga arsip dan data sekolah terbakar, namun kegiatan belajar mengajar tetap dilaksanakan pada sebagian gedung yang tidak terbakar. Pada tahun 1994 Pemerintah Kota Manado mengadakan rehabilitasi total dalam bentuk gedung bertingkat yang terdiri dari 9 ruang belajar dan terdapat ruang perpustakaan yang sederhana. Melihat perkembangan pendidikan di SD Negeri 11 Manado, maka pada tahun pelajaran 1997/1998 pemerintah mempercayakan melakasanakan program Kelas Unggulan yang dimulai dari kelas IV, V, dan VI secara bertahap sampai sekarang ini. Tahun Pelajaran 2001/2002 samapai sekarang, dipercayakan lagi oleh pemerintah kota Manado untuk melaksanakan program kelas akselerasi yang dimulai dari kelas III (Profil sekolah SD Negeri 11 Manado tahun 2014).

\section{Jumlah Siswa Menurut Agama di SD Negeri 11 Manado}

\begin{tabular}{cccc}
\hline Agama & L & P & Total \\
\hline Islam & 241 & 269 & 510 \\
Kristen & 68 & 79 & 147 \\
Katholik & 4 & 3 & 7 \\
Hindu & 4 & 6 & 10 \\
\hline Total & 317 & 357 & 657 \\
\hline
\end{tabular}

Sumber: Profil sekolah SD Negeri 11 Manado tahun 2014

Data jumlah siswa menurut agama di SD Negeri 11 Manado menunjukkan 77,7\% siswa beragama Islam. Sedangkan guru yang menangani Mapel PAI hanya dua orang. Berbanding terbalik dengan murid Kristen sebanyak 22,3\% dan terdapat 3 orang guru yang menangani siswa. Apabila 
dibandingkan dengan jumlah guru PAI yang tersedia dengan siswa, maka rata-rata rasio guru PAI dan murid muslim berbanding 1:255. Rasio ini tidak ideal menggambarkan jumlah guru PAI sangat kurang.

\section{Potret Sekolah SD Negeri 1 Bunaken Kepulauan}

SD Negeri 01 Bunaken Kepulauan Sulawesi Utara yang terletak di lingkungan 3 kecamatan Bunaken. Sekolah ini didirikan pada tahun 1908. Sekolah ini tidak terakreditasi dan masuk dalam kategori wilayah terpencil. Waktu penyelenggaraan pagi. NPSN/ NSS:40102996/ 101176005001.

Misi SD Negeri 1 Bunaken Kepulauan adalah terciptanya sekolah yang unggul dalam Iptek dan kokoh dalam Imtaq. Sedangkan misinya meningkatkan strategi pembelajaran yang menyenangkan; mengusahakan pemenuhan sarana dan prasarana pendidikan; mencukupi dan meningkatkan kualitas tenaga kependidikan; menjalin kerjasama yang baik dengan masyarakat yang peduli pendidikan; terciptanya manusiamanusia yang pintar, terampil dan berwibawa; membudayakan lingkungan yang bersih, indah, sehat, dan damai; menyukseskan program pemerintah kota. Tujuan SD Negeri 01 Bunaken Kepulauan, menjadikan sekolah sebagai ladang ilmu; industri keterampilan, budi pekerti, budaya daerah/nasional, pembangunan manusia yang bermoral; lingkungan yang bersih dan indah.

Jumlah Siswa Menurut Agama di SD Negeri 1 Bunaken Kepulauan

\begin{tabular}{cccc}
\hline Agama & L & P & Total \\
\hline Islam & 27 & 18 & 45 \\
Kristen & 49 & 47 & 96 \\
Hindu & 1 & 0 & 1 \\
\hline Total & 77 & 65 & 142
\end{tabular}

Sumber: Profil sekolah SD Negeri 1 Bunaken Kepulauan tahun 2014

Dari data jumlah siswa yang beragama Islam di SD Negeri 1 Bunakaen Kepulaun menunjukkan $31,7 \%$ siswa beragama Islam. Sedangkan guru yang menangani Mapel PAI hanya satu orang dan satu orang guru kelas yang khsuus membantu mengajarkan PAI. Sedangkan jumlah siswa yang beragama Kristen sebanyak 67,6\% yang ditangani oleh 2 orang guru.

\section{Posisi Pendidikan Agama Islam di Sekolah}

Pendidikan Agama Islam di sekolah berfungsi pertama untuk pengembangan keimanan dan ketaqwaan kepada Allah swt serta akhlak mulia peserta didik seoptimal mungkin yang telah ditanamkan terlebih dahulu dalam lingkungan keluarga. Kedua penanaman nilai ajaran Islam sebagai pedoman mencapai kebahagiaan hidup di dunia dan di akhirat. Ketiga penyesuaian mental peserta didik terhadap lingkungan fisik dan sosial melalui Pendidikan Agama Islam. Keempat perbaikan kesalahan-kesalahan, kelemahankelemahan peserta didik dalam keyakinan, pengamalan ajaran agama Islam dalam kehidupan sehari-hari. Kelima pencegahan peserta didik dari hal negatif dan budaya asing yang akan dihadapinya sehari-hari. Keenam pengajaran tentang ilmu pengetahuan keagamaan secara umum, sistem dan fungsionalnya. Ketujuh penyaluran siswa untuk mendalami pendidikan agama ke jenjang yang lebih tinggi (Dasim, 2010: 1-2).

Pengajaran PAI di SD Negeri 11 Manado dan SD Negeri 01 Bunaken Kepulauan tidak hanya dilakukan secara formal di sekolah tetapi terdapat program yang ko-kurikuler yang bermanfaat bagi peningkatan kesadaran moral peserta didiknya misalnya "taskiyah" setiap hari sabtu dan pesantren kilat. Selain itu terdapat pula kegiatan ektrakurikuler misalnya memperingati hari besar Islam dan kegiatan keagamaan lainnya. Kegiatan keagamaan dapat meningkatkan keimanan dan ketakwaaan kepada Tuhan Yang Maha Esa dan membiasakan peserta didik untuk berakhlak mulia. Manusia yang beriman, bertakwa, dan berakhlak mulia akan terbentuk melalui proses kehidupan, terutama melalui proses pendidikan.

Proses pendidikan ini berlangusng seumur hidup baik di lingkungan keluarga, sekolah, maupun di masyarakat. Dengan pendidikan agama mampu meberikan kontribusi terhadap seluruh perkembangan manusia. Tujuan dari program keagamaan atau pembinaan keimanan dan ketakwaan terhadap Tuhan Yang Maha Esa adalah memberikan pengetahuan, pemahaman, dan pengalaman melaksanakan pembiasaan keimanan dan ketaqwaan terhadap Tuhan Yang Maha Esa dalam kehidupan sehari-hari. Meningkatkan keimanan kepada Allah dan berakhlak mulia serta menanamkannya pada peserta didik melalui kegiatan pembiasaan positif. Mengamalkan nilainilai ajaran agama dalam kehidupan sehari-hari baik di sekolah, di rumah, dan di masyarakat (Gunawan, 2013: 76-77). 


\section{Jenis-Jenis Buku PAI}

Desain buku pelajaran sangat tergantung dengan desain kurikulum yang telah dibuat. Misalnya kehadiran kurikulum 2013 yang merupakan pengembangan dari kurikulum sebelumnya. Karena KTSP 2006 masih dijumpai beberapa permasalahan. Di antara permasalahannya, konten kurikulum terlalu padat dan tingkat kesukarannya melampaui tingkat perkembangan peserta didik. Kurikulum belum sepenuhnya berbasis kompetensi. Kompetensi belum menggambarkan secara holistik domain sikap, pengetahuan, dan keterampilan. Kurikulum belum tanggap terhadap perubahan sosial. Standar proses belum menggambarkan urutan pembelajaran yang rinci. Standar penilaian belum mengarah pada standar penilaian berbasis kompetensi. Dan dengan KTSP memerlukan dokumen kurikulum yang lebih rinci agar tidak menimbulkan multi tafsir. Kehadiran K-13 sebagai upaya pengembangan yang penekanannya lebih pada penyempurnaan pola pikir, pengutan tata kelola kurikulum, pendalaman dan perluasan materi, penguatan proses pembelajaran, dan penyesuaian beban belajar, apa yang diinginkan dengan yang dihasilkan. Pengembangan K-13 dilakukan atas dasar prinsip standar kompetensi lulusan diturunkan dari kebutuhan, standar isi diturunkan dari standar kompetensi inti yang bebas mata pelajaran. Semua mata pelajaran harus berkonstribusi terhadap pembentukan sikap, pengetahuan, dan keterampilan peserta didik. Mata pelajaran diturunkan dari kompetensi yang ingin dicapai. Semua mata pelajaran diikat oleh kompetensi inti. Keselarasan tuntutan kompetensi lulusan, isi proses pembelajaran dan penilaian (Direktorat Pendidikan Agama Islam, 2014: 1-2).

Dalam konteks inilah Kurikulum K-13 hadir dan didesain sedemikian rupa. Dengan selesainya desain kurikulum dan buku K-13 maka aplikasi penggunannya pun diatur dalam Peraturan Menteri Pendidikan dan Kebudayaan RI Nomor: 71 Tahun 2013 tentang Buku Teks Pelajaran dan Buku Panduan untuk Guru baik di tingkat pendidikan dasar maupun menengah, menetapkan buku pelajaran yang layak digunakan dalam pembelajaran termasuk pembelajaran Pendidikan Agama Islam dan Budi Pekerti.

Berbagai usaha pengembangan $\mathrm{K}-13$ dari lembaga telah dilakukan dalam proses selanjutnya, baik dari pihak sekolah, Diknas Provinsi maupun Kabupaten/Kota, dan Kemenag terus dilakukan.
Mulai dari persiapan pelatihan guru K-13, Bimtek, dan upaya pendistribusian sampel buku (cetak dan buku eletronik) untuk disebarluaskan di sekolah secara bertahap yang dimulai sejak tahun 2013 . Namun sejumlah sekolah baru menerapkan K-13 ini ketika semester satu berjalan pada Oktober 2014. Berbeda dengan sekolah sasaran (piloting project) yang telah menjalankan $\mathrm{K}-13$ mulai dari semsester pertama di tahun 2013, kesiapan sumber belajar berupa buku wajib K-13 telah tersedia. Ketika sekolah-sekolah berusaha menjalankan dan menerapkan program K-13 atas dasar Peraturan Menteri Pendidikan dan Kebudayaan RI Nomor 71 Tahun 2013.

Sejumlah persoalan mulai muncul. Di tahun 2014 ketika keluar Keputusan Presiden Nomor 121/P Tahun 2014 tentang Pembentukan Kementerian dan Pengangkatan Menteri Kabinet Kerja yang menetapkan Anies Baswedan menjadi Menteri Pendidikan dan Kebudayaan RI. Seketika itu juga terjadi perubahan pada pemberlakukan Kurikulum 2013 dengan dikeluarkannya Peraturan Menteri Pendidikan dan Kebudayaan RI Nomor 160 Tahun 2014 tertanggal 11 Desember 2014 Tentang Pemberkaluan Kurikulum Tahun 2006 dan Kurikulum Tahun 2013. Penekanan Peraturan Menteri Nomor 160 tahun 2014 yaitu pada satuan pendidikan dasar dan pendidikan menengah yang melaksanakan Kurikulum 2013 sejak semester pertama tahun pelajaran 2014/2015 kembali melaksanakan Kurikulum 2006 mulai semester kedua tahun pelajaran 2014/2015 sampai ada ketetapan dari Kementerian Pendidikan dan kebudayaan untuk melaksanakan Kurikulum 2013.

Khusus untuk Pendidikan Agama Islam menyusul Surat Edaran Direktorat Jenderal Pendidikan Islam Nomor SE/DJ.1/PP.00/143/2015 tertanggal 5 Januari 2015 Tentang Implementasi Kurikulum 2013 Pendidikan Agama Islam (PAI) pada Sekolah dengan pertimbangan bahwa berdasarkan Pasal 3 ayat 2 Peraturan Pemerintah (PP) Nomor 55 Tahun 2007 tentang Pendidikan Agama dan Keagamaan disebutkan bahwa Pengelolaan Pendidikan Agama dilaksanakan oleh Menteri Agama. Kurikulum 2013 ditangguhkan pemberlakuannya karena dianggap belum siap dalam melaksanakan K-13. PAI tidak termasuk dalam mata pelajaran ujian nasional tetapi kelompok ujian sekolah, sehingga penyelenggaraan dan penilaian PAI tergantung pada kebijakan sekolah masing-masing. Kementerian Agama telah melakukan Bimbingan Teknis Kurikulum 
2013 PAI bagi guru PAI sejak tahun 2013-2014. Atas dasar pertimbangan itu Kementerian Agama RI melalui Direktorat Jenderal Pendidikan Islam menerbitkan edaran bahwa Kementerian Agama tetap melanjutkan Bimtek K-2013 PAI bagi guru PAI yang belum mengikutinya dan melakukan pendampingan kurikulum bagi guru PAI yang sudah mengikuti Bimtek 2013 PAI. Melanjutkan implementasi Kurikulum 2013 PAI pada sekolah yang guru PAI-nya sudah mengikuti Bimtek K-13 PAI. Sistem penilaian dan penyusunan rapor peserta didik disesuaikan dengan kebijakan satuan pendidikan masing-masing. Kementerian Agama di Daerah, baik Kantor Wilayah Kemenag Provinsi maupun Kemenag Kab/Kota harus berkoordinasi dengan Dinas Pendidikan setempat untuk Implementasi K-13 PAI bagi sekolah-sekolah yang bukan sasaran dari Kementerian Pendidikan dan Kebudayaan.

Dengan berbgai regulasiyang telah dikeluarkan mengenai implementasi K-13. Maka sejumlah sekolah tetap menerapkan K-13 terutama pada sekolah sasaran sebagai piloting project. Sedangkan sebagian sekolah kembali menerapkan KTSP 2006. Regulasi yang dikeluarkan secara spontan sangat mengganngu penentuan kurikulum pada semester berjalan hal ini berimbas pada buku pegangan yang dijadikan pegangan bagi guru dan siswa. Posisi buku pelajaran sangat berpengaruh pada kualitas belajar peserta didik hingga capaian tujuan pendidikan baik secara kelembagaan maupun secara nasional.

Terdapat beberapa jenis buku yang terdapat di sekolah yang menjadi sasaran penelitian yaitu buku teks pelajaran (wajib), pengayaan, dan buku refrensi atau buku rujukan yang dapat memberi informasi atau penjelasan mengenai topik tertentu. Buku referensi sangat penting disediakan di perpustakaan Sekolah Dasar sebagai sumber informasi dan pengetahuan umum untuk para siswa sesuai dengan Permendiknas Nomor 24 Tahun 2007. Buku referensi yang dimaksud meliputi Kamus Besar Bahasa Indonesia, Kamus Bahasa Inggris, Ensiklopedia, buku statistik daerah, buku telefon, kitab undang-undang dan peraturan, dan kitab suci (Suhendar, 2014: 55-57; 59-68). Kitab suci yang tersedia diperpustakaan SD Negeri 11 Manado yang sesuai dengan kitab suci Islam yaitu; Alquran, Alquran dan terjemahannya.

Adapun buku yang diupayakan oleh guru PAI sebagai sumber belajar lainnya, selain buku wajib dan penunjang, hal ini cukup diapresiasi karena merupakan upaya dari pribadi guru untuk mendapatkan penjelasan lainnya selain dari buku pegangan (wajib). Terdapat Peraturan Pemerinatah Nomor 32 Tahun 2013 tentang perubahan PP Nomor 19 Tahun 2006 atas PP Nomor 19 Tahun 2005 tentang Standar Nasional Pendidikan Buku Panduan Guru adalah pedoman yang memuat strategi pembelajaran, metode pembelajaran, teknik pembelajaran, dan penilaian untuk setiap mata pelajaran dan/atau tema pembelajaran. Buku teks pelajaran adalah sumber pembelajaran utama untuk mencapai kompetensi dasar dan kompetensi inti.

Jika buku wajib dikaitkan dengan silabus, materinya telah mencakup PAI di Sekolah Dasar, namun materinya tidak akan sempurna tanpa menambahkan materi bahan ajar yang sumber dari yang lain sebagai pembanding untuk peserta didik. Misalnya buku yang diterbitkan oleh Diknas (K-13) akan berbeda penjelasannya dengan buku terbitan Erlangga. Oleh karena itu sebaiknya terdapat buku pendamping, pengayaan, dan refrensi untuk memperkaya informasi dan penjelasan yang berhubungan dengan bidang studi PAI dan sebagai bahan bacaan. Dalam PP Nomor 32 Tahun 2013 dinyatakan pula dalam Pasal 43 yang berbunyi standar sumber belajar lainnya untuk setiap satuan pendidikan dinyatakan dalam rasio jumlah sumber belajar terhadap peserta didik sesuai dengan jenis sumber belajar dan karakteristik satuan pendidikan. Jadi seharusnya setiap siswa minimal memengang satu buku pelajaran PAI (rasionya 1:1) agar bisa terbantu dalam proses pembelajaran. Namun dalam kenyataannya masih terdapat siswa yang belum mempunyai buku pegangan. Salah satu jalan keluar yang diterapkan guru PAI meminta kepada siswa untuk memfotokopi agar bisa menjadi bahan pembelajaran siswa baik di rumah maupun di kelas.

Tedapat tiga jenis buku paket yang digunakan di SD Negeri 11 Manado yaitu buku Wajib. Buku wajib merupakan acuan dasar pembelajaran siswa (pegangang guru dan siswa). Adapun buku wajib yang digunakan di SD Negeri 11 Manado terbitan Kementerian Pendidikan dan Kebudayaan RI 2013 yang berjudul Pendidikan Agama Islam dan Budi Pekerti Kelas I, Kelas II, Kelas IV, Kelas V SD/MI yang menggunakan K-13. Sedangkan buku wajib untuk kelas III dan VI menggunakan buku Senang Belajar Pendidikan Agama Islam Untuk SD KTSP2006, penerbit Esis; Erlangga. Ciracas-Jakarta.

Untuk buku penunjang menggunakan penerbit PT.Genesindo E Kids/Eplison Grup (II)-Buahbatu, Bandung. Judul bukunya mengenai Teladan 25 Nabi dan Rasul. Buku penunjang lainnya penerbit 
Multazam Mulia Utama yaitu Cerita Islam-Orang Sabar Disayang Tuhan, Cerita Islam-Abdullah bin Umar, Cerita Islam-Khabab bin Arats Ahli Membuat Pedang Zaman Rasulullah saw, Cerita Islam-Zubair Bin Awwam, Cerita Islam-Abu Ayub Al-Ansyari Pejuang Islam Yang Tak Kenal Menyerah, Cerita Islam-Meninggalkan Istana Karena Cinta Kepada Allah, Cerita Islam-Abdullah Ibnu Rawahah, Cerita Islam-Amar Bin Yasir Sahabat Yang Sangat Setia Kepada Nabi, Cerita Islam-Doa Nabi Dikabulkan Allah, Seri Cerita Islam-Mukjizat Nabi Dibuktikan Para Sahabat, Cerita Islam-Khaulah Binti Al-Azwar Srikandi Islam Yang Perkasa, Cerita Islam-Rabiatul Al-Adawiyyah Wanita Berhati Mulia, Cerita IslamPeristiwa Besar Di Sekitar Ka'bah, Cerita IslamAbdullah Bin Abbas. Penerbit Rama Edu KasitamaJakarta Timur yang berjudul Cerita Islam-Saad Bin Abi Waqqash Singa Yang Menyembunyikan Kukunya dan Tegas Namun Berhati Mulia. Buku yang diterbitkan Apollo, Surabaya Kumpulan Kaligrafi Islam.

Terdapat pula buku terbitan Kenanga Pustaka Indonesia-Larangan Banten yang berjudul A-Z Seputar Shalat Fardhu, A-Z Seputar Berwudhu, A-Z Seputar Ibadah Haji dan Umrah, A-Z Seputar Makanan Halal dan Haram. Buku yang diterbitkan Buana Cipta Pustaka-Pondok Pinang Jaksel yang judul buku Menggapai Surga Dengan Berdoa, Mencari Berkah Dengan sholat Berjamaah, Islam dan Dakwah, Sejarah Islam Dunia, Sejarah Islam Nusantara. Buku yang diterbikan oleh CV.Ghina Walafafa, Batu Ampar-Jaktim berjudul Jejak Budaya Islam Indonesia. Buku yang berjudul Melancong Ke Negeri Para Nabi diterbitkan oleh Talenta Pustaka Indonesia, Larangan-Banten Mahkota Surga Ayah Bunda Terjemahan Kitab Tazbiyatul Aulad 2, Al Minal Wa Al Nihal Terjemahan Kitab Al-Milal Wa Al-Nihal, Akhlak Al-Qur'an Terjemahan Kitab Khuluqul Qur'an 272 Hadits Qudsi, dan Al Dthafatushaniah Bila Haditsil Qudsiah buku terbitan PT.Bina Ilmu, Surabaya. Serta buku terbitan Devisi Buku Aku Anak Saleh-PT.Anak Saleh Pratama-Jaksel berjudul Komik Akhlak Mulia- Jangan Menyerah Seri 16 dan Komik Akhlak Mulia-Olimpiade Al-Quran Seri 27. Dan terdapat pula buku Penerbit PT.Bengawan Ilmu-Semarang Pendidikan Agama Islam Kelas I, Kelas II, Kelas III, Kelas IV, Kelas V, Kelas VI Kurikulum Standar Isi yang ditulis oleh Zaenuri Siroj. Adapun Jenis buku referensi yang digunakan adalah Alquran penerbit Duta Ilmu Surabaya dan Alquran dan Terjemahannya yang diterbitkan oleh Yayasan
Penyelenggara Penterjemah/Pentafsir Alquran dicetak oleh PT.Intermasa Jakarta. Jenis buku penunjang dan refrensi yang telah disebutkan di atas merupakan koleksi perpustakaan SD Negeri 11 Mando, siswa membaca dan mempelajarinya ketika jam pelajaran telah selesai atau pada jam istirahat. Buku penunjang dan referensi sebagai buku acuan yang dijadikan pengembangan materi inti.

Dalam proses penelitian ini, peneliti menemukan buku Pendidikan Agama Islam Kelas I-VI Kurikulum Standar Isi (KTSP 2006) terbitan Bengawan Ilmu-Semarang karangan Zaenuri Siroj yang terbit tahun 2010. Fungsi buku ini sebagai buku penunjang untuk kelas I-VI. Padahal seharusnya buku Pendidikan Agama Islam ini dijadikan buku wajib (khususnya kelas III dan VI) dengan alasan buku ini termasuk dalam daftar buku teks pelajaran SD sesuai Peraturan Menteri Pendidikan Nasional Nomor 32 Tahun 2010 Tanggal 12 November 2010.

Khusus untuk buku paket Pendidikan Agama Islam yang digunakan di SD Negeri 1 Bunaken Kepulauan yaitu Senang Belajar Pendidikan Agama Islam Untuk Sekolah Dasar (KTSP Standar Isi 2006) yang diterbitkan oleh Erlangga. Ciracas-Jakarta. Buku ini hanya diajarkan untuk kelas I dan kelas VI sedangkan untuk kelas II-V hanya menggunakan buku Iqra dan Belajar Shalat. Pembelajaran Agama Islam untuk kelas I dan VI diajarkan oleh guru yang hanya memenuhi jam mengajarnya untuk persiapan sertifikasi. Sedangkan untuk kelas II-V tidak mempunyai guru agama yang khusus mengajarkan PAI. Pelajaran PAI khusus kelas II-V diisi oleh guru kelas yang bernama Ibu Norma dan merupakan satu-satunya guru beragama Islam disekolah tersebut.

\section{Problem Pemanfaatan Buku Paket}

Mengenai guru PAI sesuai dengan Peraturan MenteriPendidikan Nasional No.22 Tahun 2006 pada Bab VI Standar Pendidik dan Tenaga Pendidikan meliputi kualifikasi akademik. Kualifikasi akademik yang dimaksud adalah kualifikasi akademik Guru SD/MI Guru pada SD dan MI harus memiliki kualifikasi akademik minimum Diploma 4 (D4) atau sarjana (S1) dalam bidang pendidikan SD/MI atau psikologi yang diperoleh dari program studi yang terakreditasi.

SD Negeri 11 Manado mempunyai dua guru agama, kedua guru PAI (telah dinyatakan lulus sertifikasi dan memenuhi persyaratan yang telah ditetapkan dalam Peraturan Pemerintah RI No.9 tahun 2005 tentang Standar Nasional 
Pendidikan yang mensyaratkan guru minimal memiliki kualifikasi akademik minimal sarjana (S1) atau diploma dengan mempertimbangkan masa kerja, usia, kediklatan yang diikuti dan jabatan/ tugas tambahan. Berbeda dengan guru PAI yang di SD Negeri 01 Bunaken Kepulauan. Kualifikasi akademik lulusan Madrasah Aliyah (ibu Maya) dan belum tersertifikasi, menjalankan tugas di SD Negeri 1 Bunaken Kepulauan untuk kelas I dan VI, pengabdian ini dilakukan untuk pemenuhan jam pelajaran Agama yang harus tercukupi. Sedangkan tempat tugas pokok ibu Maya di SD Inpres Bunaken. Sedangkan ibu Norma yang mengajarkan PAI untuk kelas II-V lulusan diploma dan berstatus sebagai guru kelas. Pengajaran PAI yang dilalukan hanya karena keprihatinan dan kepedulian dengan anakanak yang beragama Islam.

Kedua data tersebut guru SD Negeri tersebut jauh berbeda. Guru PAI SD Negeri 11 Manado telah melalui uji kompetensi untuk memperoleh sertifikat pendidik. Sedangkan guru PAI SD Negeri 01 Bunaken Kepulauan belum melalui uji kompetensi. Padahal uji kompetensi merupakan penilaian dalam bentuk portopolio yang merupakan pengakuan atas pengalaman profesional guru dalam bentuk kumpulan dokumen yang mencerminkan kompetensi guru. Komponen penilaian mencakup: kualifikasi akademik, pendidikan dan pelatihan, pengalaman mengajar, perencanaan dan pelaksanaan pembelajaran, penilaian dari atasan dan pengawas, prestasi akademik, karya pengembangan profesi, keikut sertaan dalam forum ilmiah, dan pengalaman organisasi (An-Nahidl dkk, 2010: 50). Selain itu guru harus mempunyai kompetensi pedagogik, kompetensi kepribadian, kompetensi social, dan kompetensi profesioanl. Kompetensi tersebut salah satu keguanaannya untuk pengembangan dan penguasaan materi pelajaran dari sumber belajar (Daryanto, 2013: 230-238).

Mekanisme pengadaan dan buku siswa dan pegangan untuk guru buku K-13, menggunakan sistem tender dengan penggunaan Lembaga Kebijakan Pengadaan (barang dan jasa) Pemerintah (LKPP). Pihak tersebut wajib menyediakan buku untuk sekolah di tingakat kabupaten atau kota di seluruh Indonesia. Dari pihak LKPP kemudian ditenderkan ke perusahaan pemenang tender (perusahaan percetakan) sebanyak 30 percetakan. Perusahaan percetakaninipulayangwajibmelakukan distribusi ke sekolah-sekolah. Dalam proses inilah pencetakan mengalami kendala keterlambatan pencetakan dan pendistribusian kesejumlah wilayah di Indonesia yang mengakibatkan buku yang akan digunakan untuk siswa dan guru tidak diterima oleh pihak sekolah yang memerlukannya. jadi pihak LKPP hanya penghubung (connector).

Masalah pengadaan dan distribusi buku cukup kompleks. Misalnya, dari 30 lebih percetakan pemenang tender. Enam di antarapemengang tender mengundurkan diri karena biaya cetak lebih dulu harus ditanggung pihak perusahaan. Salah satu pihak perusahaan pemegang tender yaitu PT Temprina Media Graffika (perusahaan di bawah Tempo Group.

Mulat Chichi sebagai Manager Operasional PT. Temprina Media Grafika menjelaskan pada media (http://radarpena.com/read/2014/09/13/11710/6/2/ Keterlambatan-Buku-K13-Tengah-Diaudit) menyatakan telah menyelesaikan pengadaan tepat waktu sebelum deadline yang tercantum dalam kontrak. Dan tidak menyangkal adanya keterlambatan dalam pendistribusian buku ke sekolah. Keterlambatan itu dikarenakan perusahannya menerima limpahan dari percetakan yang mengundurkan diri. Perusahaan menerima tugas menyelesaikan untuk 11 wilayah. Kesebelas wilayah tersebut yaitu Sumatera Selatan, Lampung, Bengkulu, Nusa Tenggara Barat, Bali Sulawesi Selatan, Sulawesi Tenggara, Sulawesi Barat, Sulawesi tangah, Gorontalo, dan termasuk wilyah Sulawesi Uatara. Terkait pendistribusian buku ke sekolah yang membutuhkan waktu lebih lama sesuai dengan wilayah tersebut seperti Sulawesi Utara dan maslah ekspedisi kerena jumlah armada dan termasuk imbas pencabutan subsidi BBM.

Berbeda dengan pengadaan buku KTSP 2006 yang diusahakan sendiri dari pihak sekolah. Sekolah hanya menentukan buku terbitan sesuai kebutuhan sekolah dan dibeli langsung dari penerbit dengan menggunakan dana BOS. Meskipun demikian pengadaan buku ini maksimal dimanfaatkan peserta didik dikarenakan buku belum berbanding rasio 1:1 antara jumlah siswa dan buku, tidak tersedianya stok buku wajib di perpustakaan, serta buku hanya boleh digunakan di dalam kelas ketika pelajaran PAI berlangsung dan tidak boleh dibawa pulang ke rumah.

Selain buku terdapat pula faktor lain sebagai problem PAI dalam pembelajaran yaitu siswa sekolah berasal dari latar belakang yang beragam tingkat pengalaman, pemahaman, serta penghayatan agamanya yang idealnyamasing-masing jenis siswa diperlakukan berbeda sesuai dengan karekteristik masing-masing; terdapat kesan yang kuat bahwa 
pendidikan agama menjadi tanggung jawab guru agama semata; pendidikan agama selama ini cenderung menggunakan penilaian kognitif (Prasastowo, 2014: 14-15).

\section{PENUTUP}

SD Negeri 11 Manado yang menjadi piloting project menggunakan K-13 (kleas I, II, IV, V) dalam pembelajaran. Ketersediaan buku khususnya buku Pendidikan Agama Islam K-13 di SD Negeri 11 Manado belum maksimal dan masih jauh dari teori ideal karena setiap murid belum berbanding satu siswa-satu buku. Sekitar $10 \%$ siswa belum mempunyai buku pegangan. Salah satu solusinya dengan cara memfotkopi buku PAI bagi anak mampu secara materi. Sedangkan buku agama yang menggunakan KTSP 2006 menggunakan penerbit Erlangga. Buku PAI ini disediakan oleh pihak sekolah dengan cara bekerjasama dan memesan kepada penerbit dengan menggunakan dana BOS.

Berbeda dengan SD Negeri 1 Bunaken Kepulauan, distribusi buku PAI sangat timpang. Untuk buku K-13 khususnya pelajaran agama tidak terjangkau sampai kepulau-pulau. Buku sebagai sumber belajar tidak dimiliki oleh siswa sebgai buku pegangan mereka mulai dari kelas I -VI. Solusinya guru hanya mendikte atau menuliskan di papan tulis dan muridnya mencatatnya. Memfotokopi buku seperti yang dilakukan oleh SD 11 Manado tidak diterapkan dengan pertimbangan kondisi sosial dan ekonomi. Biaya memfoto kopi buku untuk "anak pulau" merupakan hal yang mahal. Khusus kelas II, III, IV, dan V SD Negeri 11 Bunaken Kepulauan, tidak mempunyai buku wajib baik pegangan guru dan siswa yang sesuai standar kurikulum K-13 ataupun KTSP 2006. Hal ini disebabkan guru bidang studi PAI tidak ada.

\section{UCAPAN TERIMA KASIH}

Ucapan terima kasih kepada bapak Dr.Abdul Haling, M.Pd sebagai konsultan pada penelitian ini, banyak masukan dan kritik konstruktif yang telah diberikan untuk penyempurnaan artikel ini. Ucapan yang sama kepada Dinas Pendidikan Provinsi Sulawesi Utara khususnya bagian Badan Akreditasi, kepala sekolah SD Negeri 11 MANADO dan SD Negeri 1 Bunaken Kepulauan beserta guru dan stafnya, terkhusus untuk guru penanggung jawab Pendidikan Agama Islam SD Negeri 11 MANADO dan SD Negeri 1 Bunaken Kepulauan. Terima kasih pula kepada rekan-rekan yang telah memberikan sumbang saran, kritikan, dalam penulisan ini.

\section{DAFTAR PUSTAKA}

An-Nahidl, Nunu Ahmad dkk. 2010. Pendidikan Agama di Indonesia Gagasan dan Realitas. Puslitbang Pendidikan Agama dan Keagamaan Badan Litbang dan Diklat Kementerian Agama RI.

Badan Pusat Statistik Sulawesi Utara. Sulawesi Utara dalam Angka 2014.

BAP-S/M Provinsi Sulawesi Utara. Direktori Hasil Akreditasi Sekolah/Madrasah Tahun 2007-2010. Badan Akreditasi Nasional Sekolah/Madrasah (BAN-S/M).

Budimansyah, Dasim. 2010. Model Pembelajaran Berbasis Portopolio Pendidikan Agama Islam. Bandung: PT.Genesindo.

Daryanto. 2013. Standard Kompetensi dan Penilaian Kinerja Guru Profesional. Yogyakarta: Gava Madia.

Direktorat Pendidikan Agama Islam-Direktorat Jenderal Pendidikan Islam Kementerian Agama RI. 2014. AgamaPanduan Umum Implementasi Kurikulum 2013 Pendidikan Agama Islam dan Budi Pekerti Sekolah Dasar (SD). Jakarta: Direktorat Pendidikan Agama Islam-Direktorat Jenderal Pendidikan Islam Kementerian Agama RI.

Gunawan, Heri. 2013. Kurikulum dan Pembelajaran Pendidikan Agama Islam. Bandung: Alfabeta.

Hamami, Tasman. 2004. "Pendidikan Agama Islam di Sekolah Umum sebagai Keharusan sejarah" dalam Jurnal Pendidikan Agama Islam .Vol. 1, No. 2, 2004.

http://radarpena.com/read/2014/09/13/11710/6/2/ Keterlambatan-Buku-K13-Tengah diaudit.

Keputusan Presiden Nomor 121/P Tahun 2014 tentang Pembentukan Kementerian dan Pengangkatan Menteri Kabinet Kerja.

Mansur dan Mahfud Junaedi. 2005. Rekonstruksi Sejarah Pendidikan Islam di Indonesia. Jakarta: Departemen Agama Direktorat Jenderal Kelembagaan Agama Islam..

Peraturan Menteri Pendidikan dan Kebudayaan RI Nomor 160 Tahun 2014 tertanggal 11 Desember 2014 Tentang Pemberkaluan Kurikulum Tahun 2006 dan Kurikulum Tahun 2013.

Peraturan Menteri Pendidikan dan Kebudayaan RI Nomor: 71 Tahun 2013 tentang Buku Teks Pelajaran dan Buku Panduan untuk Guru.

Peraturan Menteri Pendidikan Nasional Nomor 32 Tahun 2010 Tanggal 12 November 2010.

Peraturan Pemerinatah Nomor 32 Tahun 2013 tentang perubahan PP Nomor 19 Tahun 2006 atas PP Nomor 19 Tahun 2005 tentang Standar Nasional Pendidikan Buku Panduan Guru. 
Permendiknas Nomor 24 Tahun 2007

Prasastowo, Andi. 2014. Pembelajaran KonstruktivistikScientiefic Untuk Pendidikan Agama di Sekolah/ Madrasah. Jakarta: PT.Raja Grafindo Persada.

Profil Sekolah SD Negeri 1 Bunaken Kepulauan Tahun 2014.

Profil Sekolah SD Negeri 11 Manado Tahun 2014.

Rahmini. 2014. "Penggunaan Buku Pendidikan Agama Islam dan Budi Pekerti Kelas VII Terbitan Kemendikbud Tahun 2013 Sebagai Bahan Ajar Mata Pelajaran PAI Siswa SMPIT Abu Bakar Yogyakarta" dalam Skripsi. Jurusan Pendidikan Agama Islam Fakultas Ilmu Tarbiyah dan Keguruan Universitas Islam Negeri Sunan Kalijaga Yogyakarta.
S.Rahman, Muhammad. 2013. "Urgensi Penggunaan Sumber-Sumber belajar Terhadap Peningkatan Efektifitas Belajar Siswa dalam Bidang Studi Pendidikan Agama di SMU Negeri 4 Manado" dalam Laporan Penelitian. Sekolah Tinggi Agama Islam Negeri (STAIN) Manado.

Suhendar, Yaya. 2014. Panduan Petugas Perpustakaan Cara Mengelola Perpustakaan Sekolah Dasar. Jakarta: Pernada Group.

Surat Edaran Direktorat Jenderal Pendidikan Islam Nomor SE/DJ.1/PP.00/143/2015 tertanggal 5 Januari 2015 Tentang Implementasi Kurikulum 2013 Pendidikan Agama Islam (PAI).

Undang-Undang No.20 Tahun 2003 Tentang Sistem Pendidikan Nasional.

Undang-Undang Nomor 2 Tahun 1989 tentang Sistem Pendidikan Nasional. 